\title{
The Comparison of the Levels of Leukotriene B4, TGF- $\beta 1$, Collagen in Keloid Fibroblasts and Normal Skin Fibroblast
}

\author{
Yuli Kurniawati',2, Oki Suwarsa², Achadiyani Agung², Sudigdo Adi' \\ ${ }^{1}$ Dermatologyand Venereology Department, Faculty of Medicine, UNSRI/RSUP MH, Palembang, Indonesia \\ ${ }^{2}$ Postgraduate School of Medicine, UNPAD, Bandung, Indonesia \\ Email: yulikurniawati@unsri.ac.id
}

Received 21 May 2016; accepted 22 July 2016; published 27 July 2016

Copyright (C) 2016 by authors and OALib.

This work is licensed under the Creative Commons Attribution International License (CC BY). http://creativecommons.org/licenses/by/4.0/

(c) (i) Open Access

\section{Abstract}

Keloid pathogenesis occurs due to the longer duration of inflammation and the increase in the production of several factors such as TGF- $\beta 1$ that causes the increase of fibroblast proliferation and collagen synthesis. The role of B4 Leukotriene (LTB4) in keloid pathogenesis particularly in the inflammation phase and tissue proliferation has not been clearly elucidated. The present study was to analyze the levels of LTB4, TGF- $\beta 1$ and collagen in keloid fibroblast and normal skin fibroblast. Fibroblasts were cultured by applying explant method to the keloid and normal skin of the petient with the keloid. The measurement of the levels of LTB4, TGF- $\beta 1$ and collagen was conducted by using Elisa method and triplicate was conducted subsequently. Statistic testing was performed through unpaired $t$ test. The experiment was carried out in cell culture laboratory of The Faculty of Medicine Padjajaran University Bandung. The levels of LTB4, TGF- $\beta 1$ are higher in keloid fibroblast, despite the fact that it does not show statistically significant difference. The level of collagen 1 is higher than that of collagen 3 in keloid fibroblast. Leukotriene B4 (LTB4) is one of the derivative of arachidonic acid that plays the role as lipid mediumtor of inflammation and fibroblast chemoattractant. The levels of LTB4, TGF- $\beta 1$, collagen 1 and collagen 3 increase in keloid fibroblast. Such a result shows the role of LTB4 in the inflammation process that stretches in keloid pathogenesis.

\section{Keywords}

Collagen, Keloid Fibroblast Leukotriene B4, TGF- $\beta 1$

Subject Areas: Dermatology

How to cite this paper: Kurniawati, Y., Suwarsa, O., Agung, A. and Adi, S. (2016) The Comparison of the Levels of Leukotriene B4, TGF-81, Collagen in Keloid Fibroblasts and Normal Skin Fibroblast. Open Access Library Journal, 3: e2801. 


\section{Introduction}

Keloid is scar tissue on the skin as a result of abnormal responses of wound recovery. Keloid occurs due to the increase in fibroblast production and collagen synthesis, thus it is included as fibroproliferative diseases [1]-[5]. Keloid incidents are estimated 15\% - 20\% among Afro-Americans, Hispanics, and Asians [6] [7]. Keloid is stil regarded as an issue in dermatology since the pathogenesis of keloid has not yet been fully understood [2] [3] [7], as a consequence, the medication results to keloid have not shown satisfactory results. Therefore, an understanding of the cellular and mollecular processes underlying the formation of keloid is crucial as the foundation to perform better therapeutic interventions [6].

Keloid pathogenesis occurs because of longer duration of inflammation and the increase in the prduction of several growth factors including Platelet Derived Growth Factor (PDGF), Transforming Growth Factor- $\beta$ (TGF- $\beta$ ), and Vascular Endothelial Growth Factor (VEGF). Transforming Growth Factor- $\beta$ (TGF- $\beta$ ) pays a part in fibriblast proliferation. Transforming Growth Factor- $\beta 1$ stimulates the production of collagen, thus it plays an important role in fibrosis pathogenesis. In the remodeling phase, TGF- $\beta 1$ serves a function in collagen synthesis especially collagen type 1 and 3 . In addition, it also plays a role in inhibiting metalloproteinase (MMP) MMP1, MMP3, dan MMP9. Transforming Growth Factor- $\beta 1$ stimulates the synthesisof tissue inhibitor of metalloproeinase (TIMP-1) that prevents collagen degradation. When the wound recovery completes, the level of TGF$\beta$ is back to normal, yet such a level increases in keloid [1] [2]. In keloid, TGF- $\beta 1$ increases resulting in the increase of fibroblast proliferation and the increase of collagen synthesis that is not suitable with the need [1] [3] [8] [9].

One of the responses in abnormal wound recovery is longer duration of inflammation phase [2] [3] [10]. Due to the damage of the membrane cell, phospholipid, which is the membrane cell structure, produces arachidonic acid with the help from phospholipase enzyme. In the inflammation phase, inlfammation mediumtors will emerge, one of such mediumtors is lipid mediumtor, which is leukotriene (LTs) [11] [12].

Leukotriene is one of arachidonic acid metabolites derived from 5-lipoxygenase pathway (5-LO) [4] [11]-[14]. Leukotriene is synthesized mainly by leukocytes and different types of cells by means of trancelullar metabolism including neutrophils, platelets and vascular cells. Leukotriene has stimulating effects of fibroblast proliferation, collagen synthesis and myofibroblast differentiation [15] [16]. In addition to leukocytes, macrophage and monocyte also produce LTB4. Leukotriene B4 is a potent inflammation lipid mediumtor. The LTB4 mainly serves as leukocyte chemoattractant and it serves in inflammation phatogenesis, immune diseases and fibrosis [12] [16].

Eicosanoide LTB4 can also be found in skin diseases such as atopic dermatitis and psoriasis and systemic sclerosis. In in vitro research of systemic sclerosis fibroblast, the level of LTB4 increased compared to healty skin fibroblast [17] [18]. The role of LTB4 in keloid phatogenesis particularly in inflammation phase and tissue proliferation in the process of wound recovery has not been thoroughly understood. Therefore, this study is intended to analyze the levels of LTB4, TGF- $\beta 1$, collagen 1 and collagen 3 in keloid fibroblast and healthy skin fibroblast.

\section{Research Method}

\subsection{Materials}

The materials of this study are keloid fibroblast culture deriving from the primary culture of keloid tissue of and normal skin fibroblast culture of a patient. The fibroblast culture used was the third subculture. The inclusion criteria of this study included a patient's keloid that has never been treated, the viability of the cell in the primary culture $>80 \%$, while the exclusion criterion was the cell that grows in the culture instead of a fibroblast. The samples consisted of keloid fibroblast culture and normal skin fibroblast. The parameters meaured were the levels of LTB4, TGF- $\beta 1$, collagen 1, collagen 3 in keloid fibroblastand norma skin fibroblast by using ELISA method. The test was conducted with 3 retests (triplicate). The patient whom keloid tissue was sampled was 1 person and was given explanation on his study and signed informed consent. The patient underwent elliptical excision of the keloid in accordance with the standar operating prosedure (SOP). The determination of keloid diagnosis was undertaken by a specialist in skin and veneral diseases. Afterwards, the excision of the tissue was prepared to create the primary culture.

The scheme of the study is presented in the following diagram. 


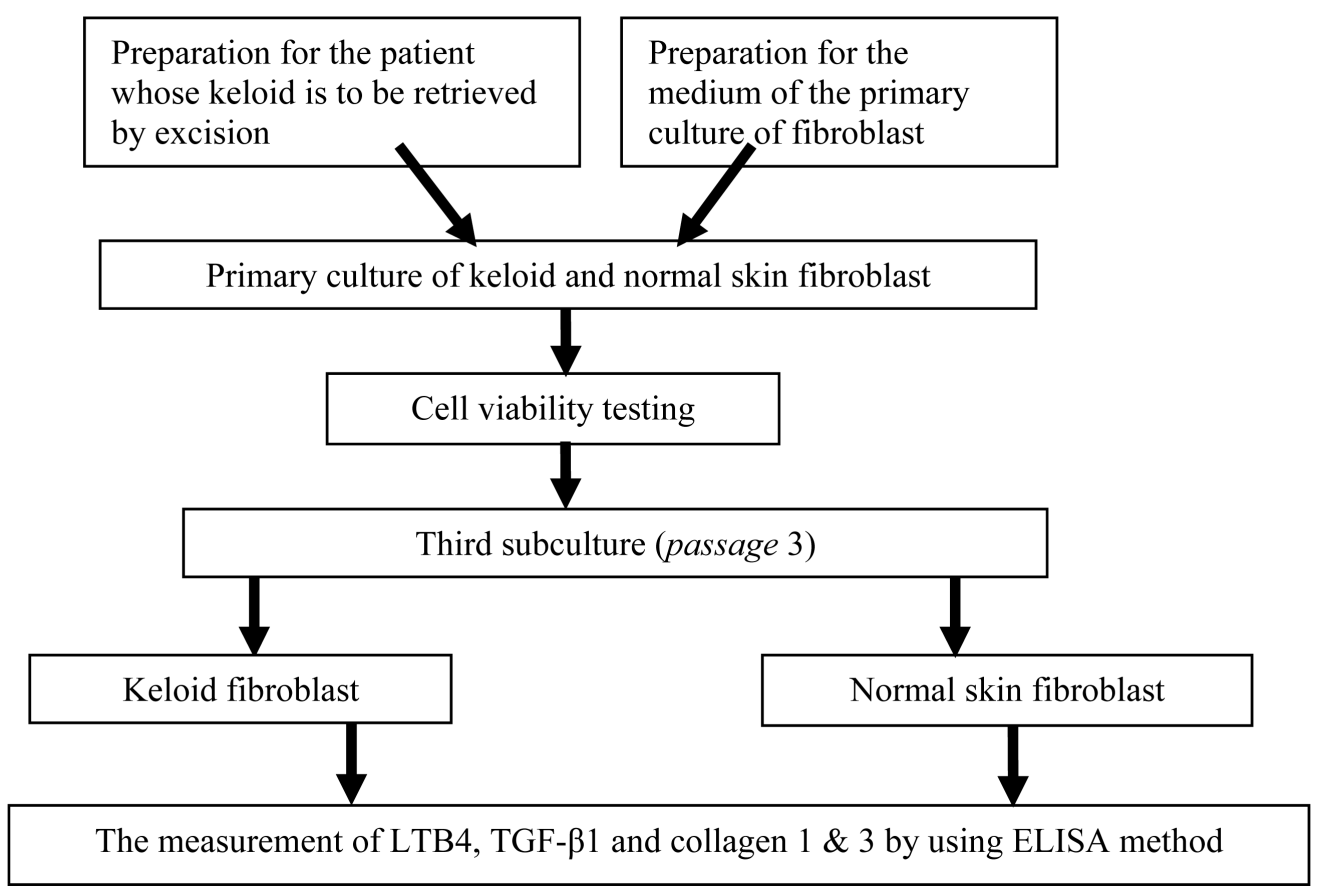

\subsection{The Procedures of Primary Culture by Using Explant Method}

1) The keloid tissue sampled from excision is directly inserted into $50 \mathrm{ml}$ centrifugal tube into which sterile PBS has been inserted, then the tissue is washed by shaking the tube slowly. Shake it three times in 10 minutes each time. Bear in mind, the process of fibroblast culture has to be carried out immediumtely, with no less than 6 hours.

2) The sample is moved into a petri dish and remove the epidermic part by using scissors, sterile scalpel. Retrieve the fibrosis tissue and wash it again by using sterile PBS.

3) The sample is put into the lid of a $100 \mathrm{~mm}$ tissue culture dish and cut it into thin pieces approximately 2 - 3 $\mathrm{mm}^{2}$.

4) 5 - 10 pieces of the sample is put into $35 \mathrm{~mm}$ tissue culture dish (seal the sample with $22 \mathrm{~mm}$ glass coverslip carefully).

5) Several drops of culture medium DMEM/RPMI $4^{\circ} \mathrm{C}$ are added under the cover glass, drop it slowly from the tip. Then add 1 - $2 \mathrm{ml}$ DMEM/RPMI again slowly and do not let it get soaked.

6) The culture is put into an incubator with the humidity of $37^{\circ} \mathrm{C}, 5 \% \mathrm{CO}_{2}$. Around $24-72$ hours after the isolation, the fibroblast cell will be a complete fibroblast cell. The fibroblast morphology is a cell in the shape of spindle and it grows on the tip of the explant.

7) The growth of the fibroblast is checked every 3 - 4 daysand the medium is changed. The growth of the fibroblast is observed, if the growth is even until it reaches the bottom of the disharound $80 \%$, subculture can be carried out (Figure 1).

\subsection{Subculture}

1) All the medium is sucked, wash the dish by sterile PBS.

2) Tripsin $0.25 \%$ is included as much as $1 \mathrm{ml}$ and then it is incubated with the temperature $37^{\circ} \mathrm{C}$. In $3-5$ minutes, the shape of the cell changes from spool into circular/round. Put the whole medium as much as 3 ml.Pipeting is done until all the cells detach from the bottom of the dish and form cell suspension.

3) Suck all the cell suspension, then move it into a sterile centrifuge tube.

4) Centrifuge the cell suspension in $150 \mathrm{G}$ in 10 minutes, the supernatant is removed.

5) Take a pellet and add $100-200 \mu \mathrm{l}$ culture medium fresh $4^{\circ} \mathrm{C}$.

6) Mix $10-20 \mu \mathrm{l}$ cell suspensionwith the same amount $0.4 \%$ trypanblue/PBS in $50 \mathrm{ml}$ centrifuge tube, then count the cell by using hemocytometer, the number of the living cells have to reach $>90 \%$. 


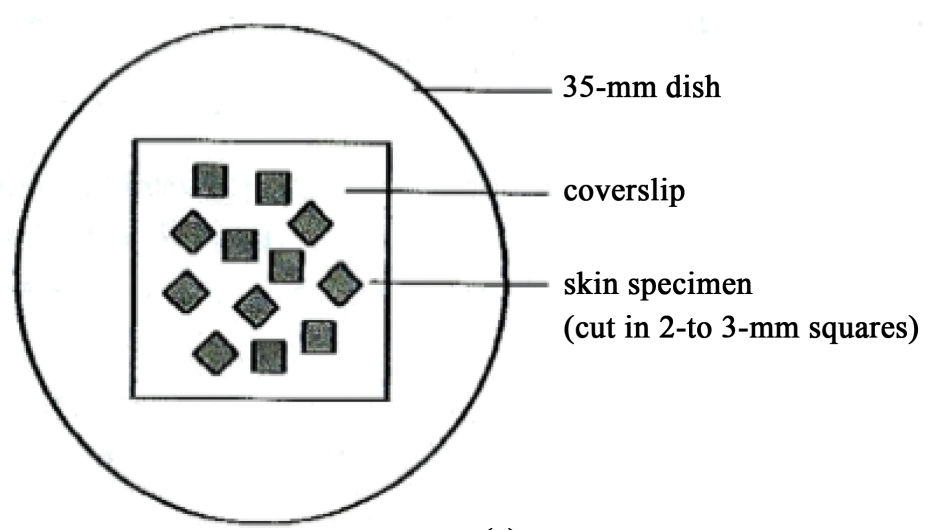

(a)

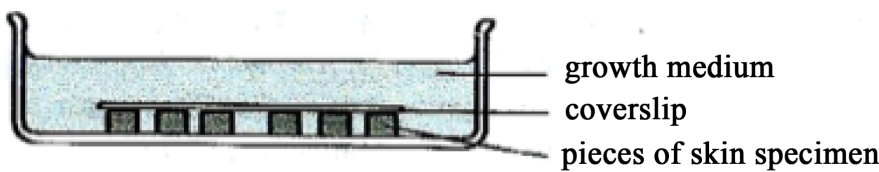

(b)

Figure 1. The position of the skin specimen on the culture medium. Source: Akira T [19].

7) Put 3 - $10 \times 10^{4}$ of the living cells into $5 \mathrm{ml}$ medium in $25 \mathrm{~cm}^{2}$ tissue culture flask.

8) Change the medium every 3 - 4 daysuntil the cell growth is $60 \%-80 \%$.

9) The next procedure is carried out until at least the third subculture, then the next procedure can be executed.

10) The cell suspension is made with the concentration of $4 \times 10^{4} \mathrm{cell} / \mathrm{ml}$ content of each well, and with $50 \mu \mathrm{l}$ cell suspension, conduct triplet.

11) Let the cell attaches to the incibation in 2 hours in the incubator with the temperature $37^{\circ} \mathrm{C}$ and $5 \% \mathrm{CO}_{2}$, add the medium until $200 \mu$ l. Then incobate it in 24 hours.

12) Measure the levels of TGF- $\beta$ 1, collagen 1andcollagen 3 by using ELISA method (ELISA checking procedures in accordance with the kit).

The results of the data collection is managed and analized statistically and it is presented in the forms of a table and graphics. The data is then tested by using one way ANOVA, after it is proven that all the data are normally distributed. The value of significance of this study is when the analyzed variables have the coefficient $\mathrm{p}<0.05$

\subsection{The Result of the Study}

Based on Table 1, the levels of LTB4, TGF- $\beta 1$ are higher in keloid fibroblast, despite the fact it does not show statistically significant difference ( $\mathrm{p}>0.05$ ). The level of collagen 1 is higher than collagen 3 in keloid fibroblast.

\section{Discussion}

Researching keloid can be done in different ways, yet the method most commonly used is basic reearch by using animal testing and tissue culture [20]. Tissue culture is the main method to conduct cellular physiology research without the interference from local factors or systemic factors in organisms. This method can detect cell regulatory mechanisms on gene expression and cell signalling levels. Keloid can only be found in humans, thus, researching animals will be very difficult to conduct [21]. Several studies have been conducted to find out the location of keloid lesion that are sampled for culture. The result of the study conducted by Giugliano et al.states that fibroblast culture grows faster on the center part of the lesion compared to the tip of the lesion and normal skin Other researchers contend that the fibroblast derived from keloid lesion peripheral produces higher collagen type 1 and 3 compared to intra-lesion and extra-lesion [21] [22]. In this study, the fibroblast cultured is derived 
Table 1. The comparison of the levels of LTB4, collagen 1, collagen 3,and TGF $\beta$-1between the keloid and the normal skin.

\begin{tabular}{|c|c|c|c|}
\hline \multirow{2}{*}{ Variables } & \multicolumn{2}{|c|}{ Groups } & \multirow{2}{*}{$\mathrm{p}^{*}$ coefficient } \\
\hline & Keloid Skin & Normal Skin & \\
\hline \multicolumn{4}{|l|}{ 1. LTB4 } \\
\hline Average (SD) & 23,107.1 (816.1) & 22,141.9 (1437.5) & 0.369 \\
\hline Range & $22,262.5$ - 23891.3 & $21,104.3-23782.7$ & \\
\hline \multicolumn{4}{|l|}{ 2. Collagen 1} \\
\hline Average (SD) & $820.1(35.1)$ & $741.0(42.6)$ & 0.068 \\
\hline Range & $787.5-857.3$ & $703.8-787.5$ & \\
\hline \multicolumn{4}{|l|}{ 3. Collagen 3} \\
\hline Average (SD) & $277.4(16.5)$ & $216.1(75.6)$ & 0.294 \\
\hline Range & $259.3-291.8$ & $162.1-302.6$ & \\
\hline \multicolumn{4}{|l|}{ 4. TGF- $\beta 1$} \\
\hline Average (SD) & 44.45 (11.66) & $44.45(26.91)$ & 0.435 \\
\hline Range & $30.98-51.18$ & $17.54-71.36$ & \\
\hline
\end{tabular}

Note: ${ }^{*}$ based on unpaired t test.

from keloid tissue and normal skin around the lesion, as a result, the levels of LTB4, TGF- $\beta 1$, collagen 1 and 3 are higher in keloid fibroblast, despite no statistically significant difference. Such a condition is likely due to the fact that the sample retrieval was carried out to the same patient withthe same location by means of ellips excision in which the normal skin of the patient was also retrieved.

The important keloid pathogenesis is fibrosis process. Fibrosis is complex tissue disease that is marked by excessive deposit of MESS component.The disease is the reponse to abnormal recovery of a wound. Fibrosis occurs because the inflammation phase extends and chronic infectious mediator cells such as macrophage, monocyte, lymphocytesincrease and stimulate TGF- $\beta$ and fibroblast. This condition causes the increase of fibroblast proliferation and the emergence of keloid [23] [24]. The emergence of keloid is not solely due to the extension of inflammation process, but because of the imbalance between MMP-TIMP that causes MES deposit [5] [25].

Leukocyte is the main source of leukotriene. Other cells like macrophage, monocyte, fibroblast, epithelia, platelet can also produceleukotrieneLeukotriene mainly plays the role as proinflammatory mediator. In addition, it also plays a role in the regulatory functions of fibroblast and fibrous tissue in the remodelling phase of wound recovery process, and it also stimulates fibroblast proliferation, collagen synthesis and myofibroblast differentiation [16] [18] [26]. Leukotriene B4 isa potent lipid mediator produced by the activation of neutrophil, macrophage, mast cells and it is chemoattractant, in this case as fibroblast chemotaxis factor.In addition, LTB4 is chemoattractant and potent leucocyte activator that play a role in inflammation process, immune disease and fibrosis [16]. Leukotriene B4 stimulates other proinflammatory cytokine synthesis including tumor necrosis factor alfa (TNF $\alpha$ ), IL6, IL8 and fibroblas growth factor (FGF). The role of LTB4 in fibrosis is to stimulate fibroblast migration, induce collagen synthesis, differentiate fibroblast into mysfibroblast and stimulate epithel cells to synthesize TGF- $\beta$ that plays a role in fibrosis process [17] [18]. In vitro research claims that the skin fibroblast of systemic sclerosis (SSc) of a patient contains more LTB4 compared to normal fibroblast. The expression of enzyme 5-LOX to the fibroblast culture of SSc patient's skin is higher compared to normal skin fibroblast [17].

In wound recovery process, TGF- $\beta 1$ plays a role in the phases of inflammation, angiogenesis, reephitelization and the regeneration of fibrous tissue. In the remodelling phase, TGF- $\beta 1$ serves a function in collagen synthesis particularly collagen type 1 and 3 . In addtion, it also plays a role in inhibiting metalloproteinase MMP1, MMP3, and MMP9. TGF- $\beta 1$ stimulates the synthesis of tissue inhibitor of metalloproteinase (TIMP-1) that deters collagen degradation. In keloid, disregulatory occurs in the activities and production of TGF- $\beta$ that causes the fibrosis to form. [2] [6] Transforming growth factor- $\beta 1$ is the main control signal to regulate fibroblast function, which also stimlates the deposition of collagen type 1 and 3 [2] [6] [7] [25]. Transforming growth factor- $\beta 1$ stimulates the production of collagen and thus plays an important role in fibrosis pathogenesis [27]. When the process of wound recovery completes, the level of TGF- $\beta 1$ returns to normal. However, in keloid, such a level keeps increasing [1] [2]. The increase of the expressions of TGF- $\beta 1$ and TGF- $\beta 2$ as well as the increase of 
phosphorylation Smad 3 in keloid fibroblast marks the important role in keloid pathogenesis [6] [28] [29]. The level of TGF- $\beta 1$ is higher in keloid fibroblast compared to normal skin fibroblast, which marks the important role of TGF- $\beta 1$ in keloid pathogenesis [25] [29]. Keloid fibroblast produces 20 times collagen compared to fibroblast from normal skin of the same patient [1]. Some data also show the decrease of procollagen polypeptide, thus collagen deposit increases even more. Keloid fibroblast results in the production of procollagen type 1 and high fibronectin [6] [28].

\section{Conclusion}

Leukotriene B4 (LTB4) is one of the derivative of arachidonic acid that plays the role as lipid mediumtor of inflammation and fibroblast chemoattractant. The levels of LTB4, TGF- $\beta 1$, collagen 1 and collagen 3 increase in keloid fibroblast. Such a result shows the role of LTB4 in the inflammation process that extends in keloid pathogenesis.

\section{References}

[1] Dolores, W., Tzankov, A., Pulzi, P. and Hildegunde, P.K. (2009) Hypertrophic Scar and Keloids—A Review of Their Pathophysiology, Risk Factors, and Therapeutic Management. Dermatologic Surgery, 35, 171-181. http://dx.doi.org/10.1111/j.1524-4725.2008.34406.x

[2] Gauglitz, G.G., Korting, H.C., Pavicic, T., Ruzicka, T. and Marc, G.J. (2011) Hypertrophic Scar and Keloids: Pathomechanisms and Curret and Emerging Treatment Strategies. Molecular Medicine, 17, 113-125. http://dx.doi.org/10.2119/molmed.2009.00153

[3] Devika, R. And dan Arockiamary, S.N. (2011) Aetiology of Keloids-An Overview. Research in Biotechnology, 2011, 37-43.

[4] Huang, C.Y. and Ogawa, R. (2013) Roles of Lipid Metabolism in Keloid Development. Lipid in Health and Disease, 2013, $12-60$.

[5] Huang, C.Y. and Ogawa, R. (2012) Fibroproliferative Disorders and Their Mechanobiology. Connective Tissue Research, 53, 187-196. http://dx.doi.org/10.3109/03008207.2011.642035

[6] Bran, G.M., Goessler, U.R., Hormann, K., Riedel, F. and Sadick, H. (2009) Keloids: Current Concepts of Pathogenesis (Review). International Journal of Molecular Medicine, 24, 283-293.

[7] Bienias, W. and Kaszuba, A. (2012) Keloids: Current Prophylactic and Therapeutic Methods. Postep Derm Alergol, XXIX, 6, 446-450.

[8] Satori, V.F. (2012) Mechanisms of Wound Repair, Wound Healing and Wound Dressing. In: Goldsmith, L.A., Katz, S.I., Gilchrest, B.A., Paller, A.S., Leffell, D.J., Wolff, K., Eds., Fitzpatrick’s Dermatology in General Medicine, 8th Edition, Mc GrawHill, New York, 2984-2994.

[9] Profyris, C., Christos, T. and Isabel, D.V. (2012) Cutaneous Scarring: Pathophysiology, Molecular Mechanisms, and Scar Reduction Therapeutics Part I. The Molecular Basis of Scar Formation. Journal of the American Academy of Dermatology, 66, 1-10. http://dx.doi.org/10.1016/j.jaad.2011.05.055

[10] Scheml, S., Rolf Markus, S., Prantl, L., Landthaler, M. and Babilas, P. (2010) Wound Healing in the 21st Century. Journal of the American Academy of Dermatology, 63, 866-881. http://dx.doi.org/10.1016/j.jaad.2009.10.048

[11] Sadik, C.D. and Luster, A.D. (2012) Lipid-Cytokine-Chemokine Cascade Orcherstrate Leukocyte Recruitment in Inflammation. Journal of Leukocyte Biology, 91, 207-315. http://dx.doi.org/10.1189/jlb.0811402

[12] Sharma, J.N. and Mohammed, L.A. (2006) The Role of Leukotrienes in the Pathophysiology of Inflammatory Disorders: Is There a Case for Revisiting Leukotriene as Therapeutic Targets? Inflammopharmacology, 14, 10-16. http://dx.doi.org/10.1007/s10787-006-1496-6

[13] Su, W.-H., Ming, H.C., Wen, L.L., Tsung, S.T., Wen, H.C., Chien, S.C. and Peng, H.W. (2010) Non Steroid Anti Inflammatory Drugs for Wounds: Pain Relief or Excessive Scar Formation? Mediumtor of Inflammation, 2010, Article ID: 413238.

[14] Mathis, S., Venkatakrishna, R.J. and Boddulur, I.H. (2007) Role of Leukotriene B4 Receptors in Rheumatoid Arthritis. Autoimmunity Reviews, 7, 12-17. http://dx.doi.org/10.1016/j.autrev.2007.03.005

[15] Louw, L. (2000) Keloids in Rural black South Africans. Part 1: General Overview and Essential Fatty Acid Hypotheses for Keloid Formation and Prevention. Prostaglandins, Leukotrienes and Essential Fatty Acids, 63, 237-245. http://dx.doi.org/10.1054/plef.2000.0207

[16] Izumo, T., Kondo, M., Arai, N. and Nagai, A. (2010) Role of Leukotriene B4 Reseptor Antagonist in Pulmonal Fibrosis. Annals of Respiratory Medicine, 1-5. 
[17] Sylwia, C., Krzysztof, K., Marek, B. and Otylia, K.B. (2012) The Role of Leukotrienes in the Pathogenesis of Systemic Sclerosis. Folia Histochemica et Cytobiologica, 50, 180-185. http://dx.doi.org/10.5603/FHC.2012.0027

[18] Biren, N.S., Nitin, P.P. and Priyanka, P. (2008) Role of Leukotriene in Inflammation and Antileukotriene Therapy. Journal of Pharmacy Research, 1, 113-125.

[19] Akira, T. (1998) Establishment of Fibroblast Cultures. Current Protocols in Cell Biology, 2.1.1-2.1.12.

[20] Bommie, F.S., Jun, Y.L. and Sung, N.J. (2013) Models of Abnormal Scarring. BioMed Research International, 2013, Article ID: 423147.

[21] Vanina, M.T.V., Bernardo, H., Jeronimo, P.F. and Lydia, M.F. (2010) Keloid Explant, Culture: A Model for Keloid Fibroblasts Isolation and Cultivation Based on the Biological Differences of Its Specific Regions. International Wound Journal, 7, 339-348. http://dx.doi.org/10.1111/j.1742-481X.2010.00698.x

[22] Syed, F., Ahmadi, E., Iqbal, S.A., Singh, S., McGrouther, D.A. and Bayat, A. (2011) Fibroblast from the Growing Margin of Keloid Scars Produce Higher Levels of Collagen I and III Compared with Intralesional and Extralesional Sites: Clinical Implications for Lesional Site-Directed Therapy. British Journal of Dermatology, 164, 83-96. http://dx.doi.org/10.1111/j.1365-2133.2010.10048.x

[23] Jie, L., Zuleika, L.B.M. and Robert, S.K. (2010) Wound Healing. In: Robinson, J.K., William, H., Daniel, M.S. and Alina, F., Eds., Surgery of the Skin: Prosedural Dermatology, 2nd Edition, Mosby, Maryland Heights, 95-109.

[24] Xiao, J.W., Gangwen, H., Philip, O., Yasmin, S. and Allen, G.L. (2006) Role of TGF $\beta$-Mediated Inflammation in Cutaneous Wound Healing. Journal of Investigative Dermatology Symposium Proceedings, 11, 112-117. http://dx.doi.org/10.1038/sj.jidsymp.5650004

[25] Thomas, A.W. (2007) Common and Unique Mechanisms Regulate Fibrosis in Various Fibroproliferative Diseases. The Journal of Clinical Investigation, 117, 524-529. http://dx.doi.org/10.1172/JCI31487

[26] Wedi, B. and Kapp, A. (2001) Pathophysiologic Role of Leukotrienes in Dermatological Diseases, Potential Therapeutic Implications. BioDrugs, 15, 729-743. http://dx.doi.org/10.2165/00063030-200115110-00004

[27] Stephan, B., Olivera, S., Michael, S.G., Harold, B. and Marjana, T.C. (2008) Growth Factors and Cytokines in Wound Healing. Wound Repair and Regeneration, 16, 585-601. http://dx.doi.org/10.1111/j.1524-475X.2008.00410.x

[28] Seifert, O. and Ulrich, M. (2009) Keloid Scarring: Bench and Bedside. Archives of Dermatological Research, 301, 259-272. http://dx.doi.org/10.1007/s00403-009-0952-8

[29] Marry, B., Robert, D. and Noelynn, O. (1992) Keloid Fibroblast Exhibit an Altered Response to TGF- $\beta$. Journal of Investigative Dermatology, 99, 650-655.

\section{Submit or recommend next manuscript to OALib Journal and we will provide best service for you:}

- Publication frequency: Monthly

- 9 subject areas of science, technology and medicine

- Fair and rigorous peer-review system

- Fast publication process

- Article promotion in various social networking sites (LinkedIn, Facebook, Twitter, etc.)

- Maximum dissemination of your research work

Submit Your Paper Online: Click Here to Submit

Contact Us: service@oalib.com 